\title{
Analysis on the Construction of Enterprise Practice Base for Vocational Education Teachers - Taking Industrial Park as an Example
}

\author{
Ke Wei ${ }^{*}$, Yanjun $\mathrm{Li}^{2}$ \\ ${ }^{1}$ School of Economics and Trade, Wuhan Engineering Institute, Wuhan 430415, Hubei Province, China \\ ${ }^{2}$ Reform and Development Department, China Baowu Steel Group, Wuhan 430415, Hubei Province, China \\ *Corresponding author: Ke Wei, rikwei@126.com
}

\begin{abstract}
Higher vocational education is the main place for cultivating high skilled talents. Only teachers with rich skills can cultivate excellent skilled talents. In order to promote the reform of vocational education, the focus should be on building a team of high-quality professional teachers. In the Opinions on Comprehensively Improving the Teaching Quality of Higher Vocational Education that was issued by the Ministry of Education, it has been proposed that professional teachers should be encouraged to practice in enterprises, accumulate practical work experience, and improve practical teaching ability. The purpose of the vocational education community is to establish an enterprise practice base to meet the needs of the modern industry as well as effectively cultivate technical and skilled talents in line with enterprises. The industrial park industry is used as an example in this article to explore the operation mode of enterprise practice base in adapting to the development of the modern industry as well as to better serve the development of vocational teachers and the improvement of students' professional ability.
\end{abstract}

Keywords: Vocational education; Teacher; Enterprise practice; Industrial park

Publication date: September 2021; Online publication: September 30, 2021

\section{Role of enterprise practice implemented by vocational colleges in industrial parks}

The enterprise practice of vocational education teachers is a specific practical measure to promote and continuously improve their professional level through mutual dialogue, learning, discussion, reference, and imitation according to the requirements of different disciplines, majors, and training objectives based on the common needs of practical activities, such as teaching, training, and scientific research ${ }^{[1]}$. It is an important support for the professional development of vocational education teachers. A professional teacher's level is closely related to the teacher's personal career development and the students' skill cultivation. At the same time, it is also an important way to improve teachers' teaching ability, scientific research collaboration ability, skill implementation ability, innovation, and practice ability.

As an important carrier and component of industrial clusters, industrial parks are not only an important way for regional economic growth, but also an inevitable choice for the process of new industrialization. Industrial parks can carry out enterprise practice exploration for vocational teachers. Vocational colleges should take advantage of the benefits of industrial clusters, such as advanced manufacturing, high-tech industry, and modern service industry, in the industrial park so as to provide good opportunities to vocational teachers in combining theory and production, as well as teaching and scientific research. In addition, this would promote vocational college teachers to master front-line production technologies and forward-looking technical equipment as well as improve their teaching quality. Through industrial park 
practice, vocational teachers would be able to accelerate technological innovation and transformation of the enterprises, improve the efficiency of using technical equipment, solve practical problems in the production process and management of the industrial park, as well as improve the benefit scale and industrial focus ability of the industrial park. From a macro perspective, this practice can effectively connect regional economic construction, boost industrial development and upgrading, as well as improve the ability to serve local economic and social development. The construction of industrial parks provides a good opportunity for school-enterprise cooperation and industry-education integration in higher vocational colleges ${ }^{[2]}$.

\section{Basic law of practical cooperation between teachers and enterprises in vocational colleges}

The school-enterprise cooperation in China has a long history with different development marks of the times. From the integration of industry, university, and research in undergraduate education to large discipline platforms, and from school-enterprise cooperation in higher vocational education to the integration of industry and education, they are not without rules to follow although their respective forms and characteristics are different.

American scholar, Jestonfield Colton, believes that the industry-university-research cooperation in universities in the United States and other developed countries has three stages: the participation of a discipline or specialty in the local development, the substantive cooperation between multiple disciplines or specialties and the local development, as well as the active service of local industrial clusters and the reconstruction of discipline clusters or specialty clusters. From the perspective of purpose, subject, and scope, domestic scholars such as Qiuheng Shi have divided the industry-university-research cooperation into three stages of development: point-to-point output of human capital by school enterprises, face-to-face promotion of the professional service industry by specialized products, and body-to-body promotion of collaborative innovation development ${ }^{[3]}$. Under the background of industry-education integration, a new three-stage development should be formed in consideration of the views of the above scholars (as shown in Figure 1).

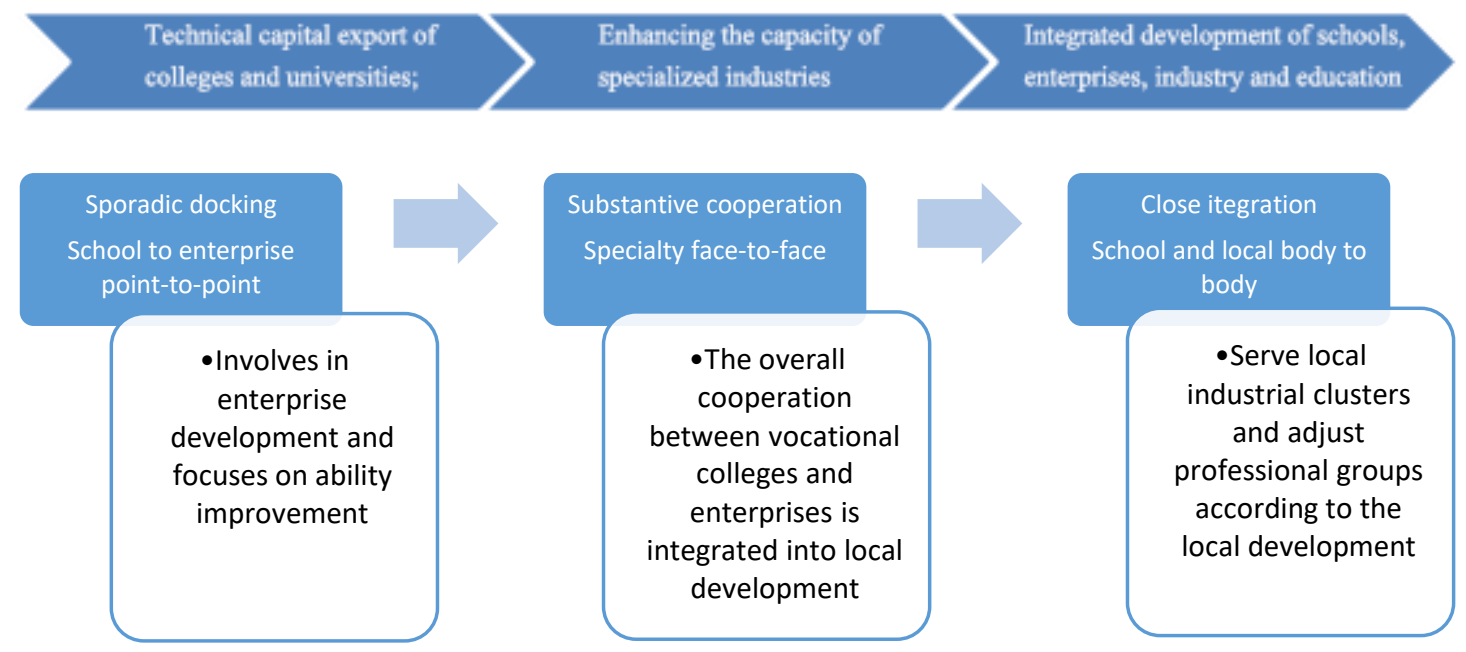

Figure 1. Three stages of industry-education integration development

The development of vocational education has entered a new era. The national "14th Five-Year Plan" introduced the goal of building a systematic vocational education. Local governments strongly advocate that vocational education should meet the requirements of "integration of industry and education, collaborative innovation, system docking, and active service," which provides a resonant condition for 
vocational colleges and industrial parks on the supply side as well as the demand side of skilled personnel training. Complying to the basic law of integrating industry and education, it is necessary for vocational teachers to participate in the enterprise practice of "key technology of resonance imaging."

\section{Orientation of the practice base of professional and vocational teachers in China Baowu Industrial Park}

The purpose of establishing China Baowu Industrial Park is to use existing land resources to develop and strengthen the modern industrial park system, provide a good industrial agglomeration environment for iron and steel enterprises in the park, improve the core competitiveness of the enterprises, drive industrial upgrading, development, and reconstruction, as well as provide coverage for the whole industrial chain supply to cultivate the next generation of intelligent manufacturing industry pattern.

China Baowu Industrial Park largely integrates stock resources on the basis of original diversified industries and carries out development on an appropriate scale, mainly focusing on manufacturing, upgrading, and transformation. Due to the industrial attribute gene of the park, China Baowu Industrial Park emphasizes more on modern manufacturing, industrial internet, and the replacement of industries attached to the original iron and steel industry. Differing from other industrial parks, this single industrial field model forms a relatively broad docking pattern between the industrial chain and the professional chain, which is conducive to the enterprise practice of higher vocational college teachers with distinctive professional characteristics. In view of that, the practice base defines the docking relationship between industry and specialty and combs the docking relationship between each specific industrial sector and the major categories in vocational education. This is convenient for professional teachers in vocational colleges to carry out specific enterprise practice (Table 1).

Table 1. Docking relationship between the education chain and industrial chain

\begin{tabular}{cc}
\hline Education chain & Industry chain \\
\hline Resource environment and security & Green city construction and industrial park construction \\
Energy, power, and materials & Urban services and industrial park construction \\
Civil construction & Green city construction, industrial park construction, and real estate center \\
Water conservancy & Urban services and green city construction \\
Equipment manufacturing & Industrial technology services \\
Food, medicine, and grain & Comprehensive living services \\
Electronic information & Big data industrial park \\
Finance and trade & Comprehensive living services, real estate center, and logistics park \\
Tourism & Comprehensive living services \\
Education and physical education & Preschool education service
\end{tabular}

\section{China Baowu Industrial Park and the types of enterprise practice among vocational teachers in college}

Wuhan Engineering Institute is a full-time ordinary higher vocational college sponsored by China Baowu Steel Group Co., Ltd. The major categories of vocational education meet the needs of skilled talents for China Baowu's strategic development. College teachers are both teachers and employees of enterprises. They have a deep understanding of industrial development and familiarity toward enterprises. At the same time, enterprises are already more open to colleges and universities, indicating that it is relatively mature to carry out teachers' enterprise practice. 
From 2019 to 2021, the institute has 23 backbone teachers involved in teachers' enterprise practice, covering civil construction, finance and trade, tourism, equipment manufacturing, electronic information, etc. In combination with the nature of various majors, full-time practice with an average resident time of three weeks has been set as the management practice, technical practice, and project replacement practice so as to meet the practical needs of teachers from different professional fields in vocational colleges.

Through practice, it has been suggested that the discipline link between different industrial sectors and professional teachers should not be carried out in the form of enterprise practice, but different types of practical projects should be carried out according to the development level of industrial parks and the current situation of the industrial layout so as to improve the fundamental purpose of teachers' acquisition of enterprise skills. After exploring the effect of enterprise practice in the recent two years in combination with the current situation of industrial development, the practice of vocational teachers in the industrial park can be divided into four types.

(1) Learning of enterprise skills

This type mainly focuses on sectors with good industrial foundation and relatively mature parks or industries, such as industrial technology services and education services. In this sector, teachers can fully understand the existing mainstream technology and equipment operation of the industry and better master the key skills required by the enterprise.

(2) Teachers' enterprise project

This type focuses on the project-based development of an industrial park and the specific projects of enterprises in the park. This is similar to the development of collaborative innovation platform. Enterprise teachers carry out practice in terms of project operation through external brain and internal brain so as to improve their skills and obtain favorable foreign aid support for their projects. This type mainly focuses on real estate development, green city construction, logistics park, big data industrial park, etc.

(3) Consulting to transform

This type focuses on the initial stage of the project or the design and transformation stage of new business model as well as operation model, which is transformed into consulting results through teachers' enterprise practice. For example, comprehensive life service, industrial park construction, etc.

(4) Integration of pre-service and post-service

As the main platform for China Baowu enterprises' staff training, Wuhan Engineering Institute refines skill points into knowledge system after enterprise practice, expands them into training courses, and carries out standardized training in enterprises to improve the overall skills and operation level of their employees as well as the overall technical ability of enterprises.

\section{Problems to be solved}

For nearly two years of practice, although some teachers have accumulated experience in enterprise practice, several problems have also been found in the process of the practice.

(1) Insufficient motivation of "mutual teaching"

Full-time teachers have adapted to the long-term classroom teaching mode, lack understanding in regard to enterprise operation and production practice, as well as relatively lack practical ability. Enterprise teachers have rich professional skills and production practice experience, but they lack professional theoretical knowledge along with poor education and teaching ability. During interaction, there are often obstacles in communication. In addition, enterprise teachers are 
enterprise employees first, in which they need to ensure that completing their own work and achieving performance indicators are their main goals, while they spend more experience on teaching and guidance. This would inevitably lead to conflicts. At the same time, due to insufficient motivation of "mutual learning" between the two sides, full-time teachers are not fully able to adapt to the enterprise environment when they begin their enterprise practice and some even have a feeling of experience gap.

(2) Inadequate practice of "safety"

"Safety" is the core concern of both sides when accepting teachers for enterprise practice. Some teachers do not have practical experience in enterprise production, neither do they have relevant professional qualifications or received safety education from enterprises. In the process of practice, they are very likely to violate the safety production system, resulting in safety production accidents. This would affect the safety production tasks of enterprises and the personal safety of the teachers. On the other hand, when full-time teachers begin their enterprise practice, they may be exposed to core technologies or trade secrets of these enterprises. The protection of enterprises' core interests has become the main concern of these enterprises.

(3) Insufficient fund guarantee mechanism

Professional teachers are involved in enterprise practice, while enterprises assign technical and skilled personnel to participate in guidance and teaching. The workload faced by these employees would certainly increase, but from the existing financial structure of the enterprise, the cost cannot be increased, especially with the limited total income of central enterprises. This does not break the management regulations, resulting in the lack of enthusiasm of enterprise employees to participate in guidance and teaching. Similarly, when teachers participate in practice, they must uniformly distribute safety equipment according to the enterprise system. However, the guarantee conditions differ due to different development of enterprises in the park. The meal expenses and transportation during the practice do not fall under the guarantee norms. Therefore, the state should establish a unified guarantee mechanism to promote the construction of teachers' practice base in enterprises.

(4) Vague definition of intellectual property rights

For teachers in involved in enterprises of the project practice type and consulting transformation type, the enterprise practice mainly focuses on intellectual output and the enterprises provide a platform for scheme implementation. The distribution of income from teachers' intellectual achievements and the ownership of property rights have become issues that need to be solved. As far as enterprises are concerned, the practice of professional teachers in the above types has achieved results, and enterprises have not signed the agreement of achievement ownership and transformation with teachers or schools. At the same time, as the practice is based on a practice agreement, enterprises cannot pay for the results or take disciplinary measures according to the practice agreement because they may cause disputes. This is what enterprises do not want to face in the construction of the practice base. Therefore, it has been suggested that to straighten out this relationship, the state and relevant departments should take these issues into their hands in order to formulate appropriate policies.

\section{Conclusion}

The enterprise practice of vocational education teachers is an important measure to vigorously develop vocational education and improve the level of vocational education teachers. It is not only necessary to actively promote the involvement of vocational education teachers in enterprise practice, but also to carry out targeted development needs that are suitable for the positioning of teachers, establish a scientific 
enterprise practice management system, strengthen the maneuverability of the practice content, intensify policy support and evaluation mechanism, improve the teaching ability level in vocational colleges, cultivate professional development skills to provide effective support, as well as achieve technological powerhouse.

\section{Project}

This article is a special project of "integration of industry and education" in the enterprise practice base of national vocational education teachers.

\section{Disclosure statement}

The authors declare that there is no conflict of interest.

\section{References}

[1] Li XZ, Wang L, 2016, Research on the Construction of Vocational Education Teachers' Practice Community. Teacher Educational Research, (1): 16-20.

[2] Yin TT, 2020, Practice of Education Mode based on "Integration of Industry and Education" in Industrial Park - A Case Study of Guangzhou Vocational College of Science and Technology Trade. Journal of Hubei Open University, (33): 22-23.

[3] Zhou HL, 2018, Research on the Cooperation and Docking between Higher Vocational Colleges and Local Industrial Parks. Journal of Educational Development, (10): 82-86

[4] Shen WQ, 2019, Study on School-enterprise Collaborative Education Model Based on Industrial Education Park - A Case Study of Suzhou Vocational and Technical College of Economics and Trade. Chinese University Technology Transfer, (10): 78-81.

[5] Yang C, 2014, Research on Production-Education Cooperation in Higher Vocational Colleges Based on Industrial Park Model. China Adult Education, (21): 106-108.

[6] Wang K, 2019, Research on Curriculum Reform Methods of Higher Vocational Colleges under the Integration of Industry and Education. Technology Wind, (36): 20-24.

[7] Zhou HL, 2018, Research on the Cooperation and Docking between Higher Vocational Colleges and Local Industrial Parks. Journal of Educational Development, (10): 82-86.

[8] Shi QH, Zhang XY, Jiao YC, 2012, Study on the Development Mode of "County-School Cooperation" in Higher Vocational Colleges. Educational Research, (7).

[9] Yin TT, 2020, Practice of Education Mode Based on "Integration of Industry and Education" in Industrial Parks - A Case Study of Guangzhou Vocational College of Science and Technology Trade. Journal of Hubei Open University, (33): 22-23.

[10] Li XZ, Wang L, 2016, Research on the Construction of Vocational Education Teachers' Practice Community. Teacher Educational Research, (1): 16-20. 